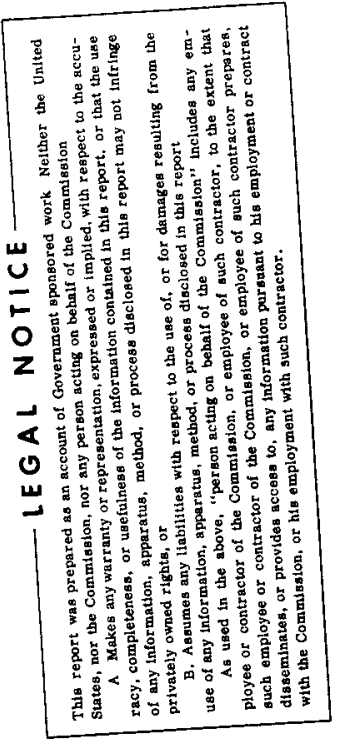

For presentation at the American Chemical Society Meeting Denver, Colorado - January 19-24, 1964
\end{abstract}

Facsimile Price \$ 1,60
Microfilm Price $\$ 198$
Available from the
Office of Technical Services
Department of Commerce
Washington 25, D. C.

GENERAL EIECTRIC COMPANY

Richland, Washington

Operated for the Atomic Energy Commission by the General Electric Company under contract \#AT(45-1)-1350 


\section{DISCLAIMER}

This report was prepared as an account of work sponsored by an agency of the United States Government. Neither the United States Government nor any agency Thereof, nor any of their employees, makes any warranty, express or implied, or assumes any legal liability or responsibility for the accuracy, completeness, or usefulness of any information, apparatus, product, or process disclosed, or represents that its use would not infringe privately owned rights. Reference herein to any specific commercial product, process, or service by trade name, trademark, manufacturer, or otherwise does not necessarily constitute or imply its endorsement, recommendation, or favoring by the United States Government or any agency thereof. The views and opinions of authors expressed herein do not necessarily state or reflect those of the United States Government or any agency thereof. 


\section{DISCLAIMER}

Portions of this document may be illegible in electronic image products. Images are produced from the best available original document. 


\title{
NEPTUNIUM RECOVERY AND PURIFICATION AT HANFORD
}

By

\author{
R. E. Isaacson and B. F. Judson \\ General Electric Compeny \\ Hanford Atomic Products Operation \\ Chemical Processing Department
}

\section{ABSTRACT}

Neptunium is routinely recovered from irradiated fuel elements at Hanford's two main separations plants. Initial development tests were started in the Purex plant in 1958, then in the Redox plant in 1959, and recently culminated in the installation of new production systems in both plants for improved recoveries. Both recovery flowsheets employ solvent extraction techniques based on the relative extractability of neptunium-VI. The neptunium is co-extracted with urantum and plutonium in the plants ' first extraction cycles and then partitioned and decontaminated in separate neptunium cycles. Excellent decontamination from fission products is achieved without interfering with mainline uranium and plutonium production. Recovered neptunium is purified by anion exchange and shipped offsite for subsequent irradiation to plutonium-238. Overall separation factors of uranium and fission products from neptunium are greater than 107 and $10^{10}$ respectively. 


\section{NEPTUNTUM RECOVERY AND PURIFICATION AT HANFORD}

\section{INIRODUCTION}

New process systems have recently been installed in Hanford's Purex and Redox plants to permit continuous production-scale recovery of neptunium-237. Neptunium is formed in Hanford's nuclear reactors as a by-product of plutonium-239 production and is recovered and purified in the chemical processing plants for subsequent conversion to plutonium-238.

The production reactor and chemical processing complex at Hanford is operated by the General Electric Company under prime contract to the U. S. Atomic Energy Comission. The Purex and Redox plants employ solvent extraction systems to separate and decontaminate plutonium from irradiated uranium for subsequent use in weapons components. The irradlated uranlum is recovered and decontaminated from fission products for reuse in the $U^{235}$ fuel and weapons systems. Recently the Purex plant has also been employed for recovery of useful fission products, including strontium-90, cesium-137, cerium-144, promethium-rare earths and technetium-99.

Recovery of the transuranic neptunium-237 was started at Purex in 1958 and at Redox in 1959 using main-line process equipment with special campaign operations for decontamination of accumulated material (Ref. 1, 2, 3). The use of the main plant system permitted rapid response to the AEC's early program needs for plutonium-238 in space power units. Increasingly higher demands for neptunium prompted a follow-up program to permit efficient and economical recovery on a continuing basis.

The following paper describes the new process systems recently installed at Hanford and summarizes program activities and process performance results to date. FORMATION OF' NEPTUNIUM

Neptunium-237 is a long-lived transuranic isotope formed by two reactions in the neutron irradiation of natural and slightly enriched uranium as shown in Table I. 


\section{TABLE I}

NEPTUNIUM FORMATION

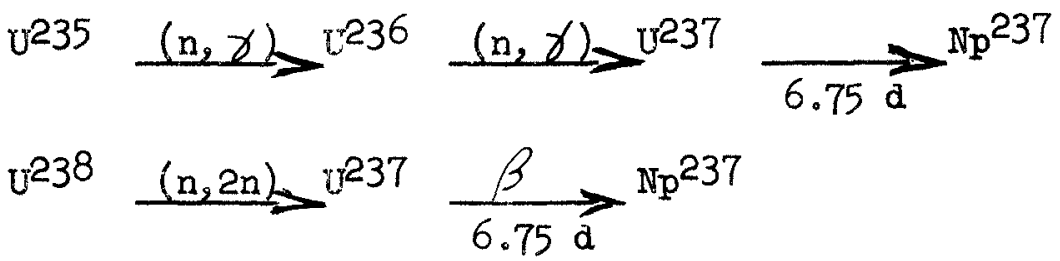

Most of the neptunium is formed by reaction of $U^{238}$ with fast neutrons. Smaller amounts are formed by slow neutron capture in $\mathrm{U}^{236}$ since appreciable amount of $\mathrm{U}^{236}$ are generated in the system by neutron capture in U235. The bulk of the $\mathrm{u}^{236}$ formed in the irradiation of natural uranium is lost to the reactor cycle when uranium is processed through the gaseous diffusion plants for isotopic enrichment. Hanford is participating in an AEC program to increase neptunium production by recycling the slightly enriched uranium stream from the reactors without processing in the cascades. Most of the U236 formed in the slightly enriched uranium is thus avallable for neutron capture in the reactors and increased overall yleld of neptunium-237. In either case, the concentration of neptunium in uranium is very small so that recovery of gram quantities in the huge separations plants is a difficult and challenging assignment. NEPIUNIUM RECOVERY AT PUREX

The process scheme used for the recovery of neptunium in Hanford 's Purex plant is shown in Figure 1. After dissolution in nitric acid, the neptunium is extracted into the 30 per cent TBP-kerosene solvent along with uranium and plutonium in the HA Column and is scrubbed for fission product removal in the HS Column. The plutonium is partitioned into an aqueous phase in the IBX Column and the neptunium and uranium comstripped in the IC Column. The IC product is concentrated and uraaium is rewextracted in the $2 \mathrm{D}$ Column. The neptunium, however, is forced into the $2 D$ raffinate stream which is concentrated for backcycle to the HA Column. Approximately one third of the backcycle stream 
is continuously processed through the new $3 \mathrm{~A}$ Column where the neptunium is ex. tracted into the organic phase. The neptunium is stripped in the $3 \mathrm{~B}$ Column and returned to the $3 \mathrm{~A}$ Column. Neptunium is thus accumulated in the $3 \mathrm{~A}$ and $3 \mathrm{~B}$ systems and is periodically decontaminated and removed to the new batch ion exchange unit for final purification and loadout.

The purpose of the $3 \mathrm{~A}$ and $3 \mathrm{~B}$ Columns in the plant is to permit continuous recovery of the neptunium and decontamination for purification without shutting down plutonium production operations. Without the new columns, neptunium can be accumulated in the uranium extraction and waste backcycle systems but can be decontaminated for removal only by special campaign processing through the plutonium decontamination system. This requires shutdown of essentially all normal process activities. In addition, accumulating the neptunium inventory within the main process system involves constant exposure to process upsets and losses of the inventory to waste streams requiring expensive and time consuming rework. The new solveat extraction battery thus permits improved plant operating efficiency.

The recovery flowsheets are based on control shifting of the neptunium between its three valence states and the relative extractability of each into the plant solvent. The process was developed in laboratory minimixer studies at Hanford using some of the valence control techniques discovered at Savannah River Laboratory (Ref。3,4). As shown in Figure 2 , neptuniumail is more extractable in 30 per cent TrE than neptunium at low acidities while at high aciaities, both are comparable. Neptuaium on the other hand is virtually inextractable. The valence state of neptunium is controlled by the use of $\mathrm{HNO}_{2}$ for catalytic oxidation to neptunium w and by the use of ferrous sulfamate for reduction to neptuniumall. Thus the neptunium is extracted as neptunium an in the HA Column by oxidation with $0.005 \mathrm{M} \mathrm{HNO} 2$ in the solvent. It is reduced to neptunium IV in the IBX Column and maintained as neptunium $\triangle$ IV in the $2 D$ and 
3A Columns by ferrous sulfamate. The neptunium wh is kept in the organis phase in the IBX Column by virtue of the low aqueous to organic flow ratio but is partitioned into the aqueous phase in the 20 Column by the high saturation of uranium in the solvent.

Flowsheet compositions for the $3 \mathrm{~A}-3 \mathrm{~B}$ systems are shown in wigure 3 for the accumulation phase of operation. Process specifications for the two columas and unique features of the equipment design are described in a seperate paper (Ref.5). During the accumulation phase, the partition demands on the system are three fold o separation of plutonium and fission products from the nept nium in the $3 \mathrm{~A}$ Column and separation of uranium from the neptunium in the 3 colimn. The 3A Column feed is maintained at high nitric acid concentration to sare

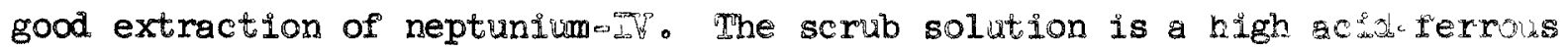
sulfamate-hydrazine solution to reduce plutonium to the inextrectable flutsnim for discharge to the raffinate. Feed flow is a 2 justed so that the uran im concentration in the solvext phase is 10.2 to prevent high neptinum losses

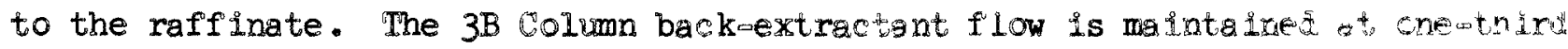
the solvent flow to strip out the neptunium into the queous phase while the same time retaining uranium in the solvent for backeycle to the fex wivm feed stream in the main plant. The $3 \mathrm{~A}$ Column raffinate is returned to the fack ycle Concentrator feed stream in the main process where the hydrazine is destroyed by nitrite reaction.

After a specified amount of neptinism is gccumulated in the systems the decontamination phase of operation is started as shown in tigure 4 . - he backcycle stream is all processed in the HA Column and a synthetic fee solution is prepared for the $3 \mathrm{~A}$ Column contalaing $4.5 \mathrm{M}$ nitric acid. "he $3 \mathrm{~A}$ Column scrub is reduced in acid and salt content and the solvent fllow decease to improve fission product decontamination. The nepturium is then retiked through the system until the separation from plutonium, uranium and fision 
products is sufficient for the ion exchrnge puxification step at which point the product flow is aiverted to the low exchange feed concentrator.

Performance of the system bas been excellent witn stable greration in the 3A avo $3 \mathrm{~B}$ Colimas at volume velocities matching Semworks Operation as shown in Table II (Ref. 6, 7). Instartaneous neptunim losses to the $3 \mathrm{~A}$ abd $3 B$ raffinate streams have been less than 0.5 per cent fot fowsteet concitions. acontamination factors across the system are sumazzed in Jable Id for the extrartion. accumlation and decontamination phases of the orerall peration. The shifts in

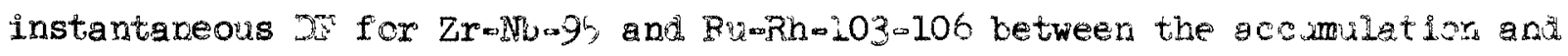
decontamination phases reflest the changes in feed an scrub aciaity and the

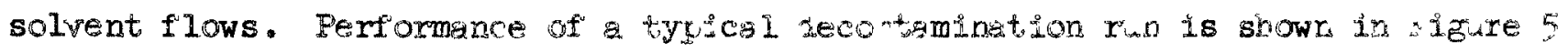
as a plot of relative 3 s yolum froduct activity levels ws. 3A solumn feed through Futs $\mathrm{s}$.

integration ot the ne, infum recovery system fnto the mainuline process has been smooth. The mir effects were changes ir. the composition of the concentrated hackcycle stream, adaiton di nitrire to the backycle. otcentrator feec ant backycle of the $3 B$ Column rafinate to the IBX volumn feed strean, all of which were accomlishe with no gherse efects on zrocess efficlency. Ferell recotery capabilities for the flant are greater twan 80 per cent with carryorer to the 2EU uranium product stream less than 10 per cent ara losses to the pre viun rafinate stream less than 10 per cent. "Nerall straraton of the uran am ard

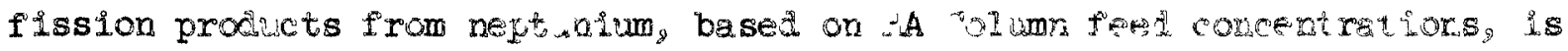

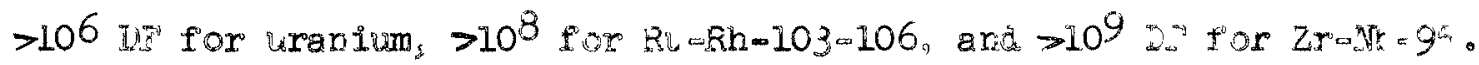
NEPTINIUN RECOTER: AN REIX X

The process schemes used for recovery of neptunim in Hanford ${ }^{\circ}$ s kedox plant are shown in Figures 6 and 7 . In the first soheme, neptunium is extracted gnd accumulated in the original equipment system and periodically decontamineted for removal by special campaign processing through the plutowiam decontaminatiun 
system. The second scheme is based on routine decontamination of neptunium through use of plutonium solvent extraction columns made available by the installation of a continuously operated prototype anion exchange contactor for plutoaium decon. tamination. In both cases, the neptunium is extracted into the hexone solvent along with uranium and plutonium in the precycle column system and is forced into the aqueous rafilnate stream separate from uranium and plutonium in the partition column system. The neptunium is accumulated by recycling between the two systems and is periodically removed to a plutonium column system for decontamination.

The recovery flowsheets are based on aqueous phase acid control and the relative extractability of neptunium ang from acid ANd solutions as compared to acidadeficient AND solutions as shown in Figure 8. The Redox process was converted from an acidadeficient feed system to an acid feed system to permit neptunirum recovery (Ref.3)。Ruthenium decontamination is better, however, with an acid deficient system so that the partition and remaining cycles remain acid deficient. Thus, the neptunium, which is oxidized to neptunium with dichromate, is extracted in the first cycle and is not extracted in the partition cycle.

In Figure 6, the neptunium from the IA Partition Column is returned to the IA Extraction Columa where it is subject to potential losses to waste as it is recextracted for accumulation. Therefore, in $\bar{k}$ igure 7 , the neptunium is returned to the IS Column for gccumulation and the rafifinate is backcycled to the HA Column, thereby minimizing potential loss.

After a specified amount of neptunium is accumulated in the IS $\backsim$ HC Column system, the inventory is removed by a special water strip through the IS Column scrub section and is transferred to the $3 \mathrm{~A}$ and $3 \mathrm{~B}$ Column previously used for plutonium decontamination. The neptunium is partitioned from residual uranium and plutonium by contact in the $3 \mathrm{~A}$ Column from an acid deficient feed thereby extracting the uranium and plutonium and segregating the neptunium in the 
raffinate. The neptunium is then extracted from an acid dichromate feed in the $3 A$ Column, stripped in the $3 B$ Column and ozonated batchwise for final ruthenium decontamination. If further decontamination is required, the process steps are repeated as necessary. The neptunium product solution is then concentrated and loaded out for final purification by ion exchange at the Furex plant.

Reserving the $3 \mathrm{~A}$ and $3 \mathrm{~B}$ Columns for neptunium decontamination rather than plutonium processing, minimizes the number of process operations otherwise required during campaign processing through the $2 A-2 B$ plutonium columns, eliminates the need for plant downotime to decontaminate the neptunium, and thus permits improved over all plant operating efficlency.

Performance of the system has been good with stable operation of the spectal purpose columas and smooth integration of the overall process system. Overall neftunium recovery capabilities for the Redox plant are greater than 90 per cent with essentislly no carryover to the $3 \mathrm{EU}$ uranium product stream and losses to the HA Colum raffinate stream of less than 10 per cent. Orerall separation of the uranium and fission products from neptinium, based on HA Column feed concen trations are $>10^{6}$ IF for uranium, $>10^{6}$ DF for RüRh-103, 106 and $>10^{8}$ DF for $Z x-M D-95$.

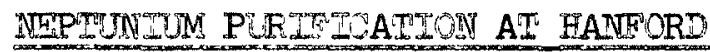

Whe neptunium recovered in the Purex and Redox plants is purified by batch anion exchange using the flowscheme shown in Figure 9 .

The neptunium product solution from the Purex solvent extraction battery is steamstripped and concentrated in a thermosychon concentrator. The neptunium is then adjusted to neptunium IV with ferrous sulfamate, stabilized with hydrazine and is loaded on an anion exchange resin column in a concentrated nitric acid medium. The product from the Redox system is ajjusted in feed composition and loaded on the resin column without prior concentration in the exchange cell. Once loaded on the resin, the neptunium is first washed with concentrated 
nitric acid containing $\mathrm{HF}_{5}$ to remove fission products. Residual fluoride is washed out of the colmond the neptunium is eluted with dilute nitric acid. The con ceatrated portion of the elint is diverted into a product tark where the neptunium is converted to the stable nerturimar valence state and the product is then bottled for shipment offsite.

Whe purpose of the aeptuaium parification facllity is to provide sufficient teanwe and concentration of the neptunium so that shipment of the product of $f^{\circ}$ site can be done safely and economically. Without such a system, shipment of a uniform zrodut from the two recovery systems could not be assured and development of altemate recovery processes would be restricted. Filute product concentrations atd higrer fission froduct levels wovld involve considerably larger and uneconomical, hegvily shieldes stifing containers。

The purification flowsheet is based on the formation of stable anioric nept anium complexes in concentrated nitric solutions and the high loading chacitus of eurtion arion exchange resins for sacn complexes. The basic exohange technique was developed at antord and the process used in the new fraclity was thoroughly tested in semiwrks systems (Ref. 8, 9). Control of the nepturium yalence in the high acid solution involyes using ferrous sulfamate with byatrazine as a holding reduetant. The ase of small conentrations of thermits relatively large fission frod sct decontamination factors tut requires extra steps for con rol. Gotrolled product elution permits recycling of dilute portions of the eluate and loading out only concentrated product so that a final concentrator system is not required.

Wowsheet eampasitions for the various steps in the purification process are shown in Table $\mathbb{W}^{r}$. Unlque features of the equipment design are discussed in a separate paper (Ref. 10). The neptunium It is logded on the resin at a temperature of $25^{\circ}$ and the relatively low rate of 8 milligrams neptunium per minite per square centimer. Most of the plutonim loads simultaneously even though the 
prevalent plutonium valence state in the feed is Pu-III. Plutonium is removed from the column at a temperature of $20^{\circ} \mathrm{C}$ by scrubbing at 4 milliliters per minute per square centimeter. A 20 column volume fission product scrub is passed through the resin at 4 milliliters per minute per square centimeter at $70^{\circ} \mathrm{C}$. Product elution is performed at ambient temperature using $0.3 \mathrm{M}$ nitric acid. The first 2 coliumn volumes are recycled to the feed so that a net neptunium concentration of 35 to 45 grams per liter can be maintained for final valence adjustment and loadout. The wastes from the loading and washing steps are treated with nitrite to destroy the hydrazine and with aluminum nitrate to complex the fluoride before entering the backcycle concentrator in the main process sytem。

Performance of the system has been good with flowsheet loading and concen tration values readily achieved (Ref.11). The neptunium loading on the resin has approeched 70 grams per liter. Decontamination factors for uranium, plutonium ard fission Troducts are sumarized in Table $V$. Product elution and fission spoivet scrubbing can be controlled by the use of a gama scintillation monitor located in the resin outlet line. Bed gassing is controlled by periodically vexting the system using a sonic probe to determine resin level and the presence of gas pockets.

SUMMARY

The installation of new process systems in Hanford's Purex and Redox plants permits the continued recovery and purification of neptunium -237 from irradiated. uranium as a comproduct of plutonium-239. The complex solventwextraction systems of the chemical processing plants have been suitably modified to incorporate the new recovery processes. Performance of the new equipment has been excellent, meeting both flowsheet and design expectations. Integration into the main plants have been smooth with overall separation of uranium from neptunium and fission products from neptunium exceeding $\mathrm{DF}^{\natural} \mathrm{s}$ of $10^{7}$ and $10^{10}$ respectively. 


\section{ACKNOWLEDCGEMENIS}

Key chemists and engineers in the start-ux of the new process systems and preparation of this paper include ip S. Buckingham, I. P. Duckworth, R. W。 Lambert, S. M. Nielson, G.A. Nicholson, H. E. Simonds, and R.A. Loder。 
REFERENCES

1. Wooper, F.R. and M. I. Walling, "r., Aqueous Processes for Seperation and Decontamination of Irradiated Fuels, Froceedings of the Second international Conference on the Peaceful Uses of Atomic Energy, Genevs, 1958, United Nations, New York, N. Y. 1958).

2. Karmon, M. K., current Status of Solvent Extraction Frocessing of Frradiated rranium Euels, BW-SA-2458, April 6, 1962.

3. Benedict, E. Eo, T.R. McKenzie and G. L. Richardson, Recovery of Meft.rium in Solvent Extraction Processes, EW-SA-1963, August 11, 1960 .

4. Sida Il, I. H. and E.K. Dukes (SRI), Kinetics of HNO2 Catalyzed 'xidation of liept anium by Aqueous Solutions of Nitric Acid, presented at 133rd ACS Meeting, San Francisco, April 1958.

5. Duckworth, T.P. and I. R. Michels, New Neptunium Recovery Facility at the Sanford Durex Plant, BWw SA-2928, March 1, 1963.

6. Ploisarison, *. ". and A. M. Plett, The Lesign and peration of Industrizl Scale Pulse Colimns for Furex Service, WW-SA-2037, November 1, 1960 .

7. Nicholson, A., Start wu and Frocess Ferformance of the Furex Neptunim Recovery System, BW-79847, Tecember 16, 1963.

8. Ryan, T. J., Concentration and Einal Furification of Neptuni.m by Anion Exchange, Ew 59193 (Rev.), September 1959.

9. Buckingham, I. S. (Unpublished Data).

10. Inckworth, $e^{\prime}$ F. and $\because$ R. PeRiviere, New Neptinium Purification Eacility at the Hanford Purex Plant, HW-SA-3282, December, 1963.

11. Nielson, S. M., Startwa and Frocess Performance of the Purex Neyt ninim Purification System, HW 79848 , Fecember 16, 1963. 


\section{TABLE II}

NEPTINIM COLOMN PERE ORMANCE AT PJREX

FLONING IINSS

$\frac{3 A \text { Column }}{\text { Fol. }}$

Cold Semiworks

1350

2200

85

70

\begin{tabular}{|c|c|}
\hline $3 B C 0$ & \\
\hline 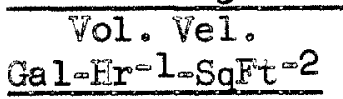 & $\begin{array}{l}\text { Freq. } \\
\text { Cycomin } 1\end{array}$ \\
\hline
\end{tabular}

Purex Cold Tests $(b)$

2150

78

1350

2000

$77^{(a)}$

1000 $70(a)$

Purex Hot Tests

Accumulation

Decontamination
1350

2200

1600
95
78

75
1300

1000
80

75

80

Notes: (a) The cold semiworks 3 B studies were made at an amplitude of 0.6 inch. The frequency listed was corrected for the 0.75 inch amplitude in the plant $3 \mathrm{~B}$ Column. All $3 \mathrm{~A}$ studies were at an amplitude of 1.1 inch.

(b) The Purex cold tests were made using $5.6 \mathrm{M} \mathrm{HNO}_{3}$ as the $3 \mathrm{AF}$ and solvent from the Purex No. 1 Solvent System as the $3 \mathrm{AX}$. 


\section{TABLE III}

NEPIUNIUM COLUMN PERFORMANCE AT PUREX

DECONTAMINATION FACTORS

Cycle

Typical Instantaneous DE

Extraction

Accumulation

Decontamination

Typical Cumulative DF's

Extraction

Accumulation

Decontamination

Overall
$\mathrm{Zr} \sim \mathrm{Mb} \sim 95$

$\mathrm{Ru}-\mathrm{Rh}-103,106$
$\underline{\mathrm{Pu}}$

8000

10

10

3

20

20

30
20

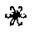

0




\section{TABLE IV}

\section{NEPTUNTIUM BATCH PURIELCATION AT PUREX}

FIOWSHEHET AND PERIRORMANGEE DATA

\begin{tabular}{|c|c|c|c|}
\hline Step & Composition & Yolumes \& Rates & Np to Backeycle \\
\hline Loading & 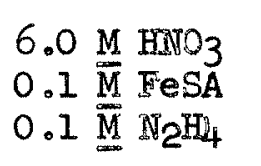 & $8 \mathrm{mg} \mathbb{N p} / \min \mathrm{cm}^{2}$ & $1.0 \%$ \\
\hline Pus Scrub & $\begin{array}{l}6.0 \mathrm{MNO} \mathrm{HNO}_{3} \\
0.1 \mathrm{MeSA} \\
0.1 \mathrm{~N}=\mathrm{NH}_{4}\end{array}$ & $\begin{array}{l}15 \text { a } 20 \mathrm{col}^{\circ} \text { vol。 } \\
4 \mathrm{ml} / \mathrm{min} \mathrm{cm}^{2}\end{array}$ & $1.5 \%$ \\
\hline FP Scrub & $\begin{array}{l}8.0 \mathrm{MMNO}_{3} \\
0.05 \mathrm{M} \mathrm{N} \mathrm{Na}_{4} \\
0.01 \mathrm{Ma}\end{array}$ & $\begin{array}{l}15-20 \mathrm{col}^{2} \text { vol. } \\
4 \mathrm{mI} / \mathrm{min} \mathrm{cm}^{2}\end{array}$ & $2.0 \%$ \\
\hline Ferub & $8.0 \mathrm{MNO}_{3}$ & $1.5 \mathrm{col} . \mathrm{vol}$. & $\angle 0.2 \%$ \\
\hline Forecut & $0.35 \mathrm{M} \mathrm{HNO}_{3}$ & $\begin{array}{l}2 \mathrm{col} \cdot \mathrm{vol}_{\circ} \\
1 \mathrm{ml} / \mathrm{min} \mathrm{cm}^{2}\end{array}$ & $($ to $3 X E)$ \\
\hline Product & $0.35 \mathrm{M} \mathrm{HN}_{3}$ & $\begin{array}{l}1 \mathrm{col} \text {. } \mathrm{vol} \text { 。 } \\
1 \mathrm{ml} / \mathrm{min} \mathrm{cm}^{2}\end{array}$ & $=$ \\
\hline
\end{tabular}




\section{TABLE Y}

\section{NEPTUNIUM BATCH PURIFICATION AT PUREX}

\section{DECONTAMINATTON FACTORS}

$\begin{array}{lcc} & \text { Typical DF's } & \text { Range of DF's } \\ \text { Zr }-N \text { Nb-95 } & 1000 & 100-1500 \\ \text { Ru }-R h-103,106 & 500 & 5-50,000 \\ U & 1500 & 10-10,000 \\ \text { Pu } & 200 & 3-300 \\ \text { TMI } & 80 & 60-100\end{array}$


FIGURE 1

\section{NEPTUNIUM ACCUMULATION - PUREX PROCESS}

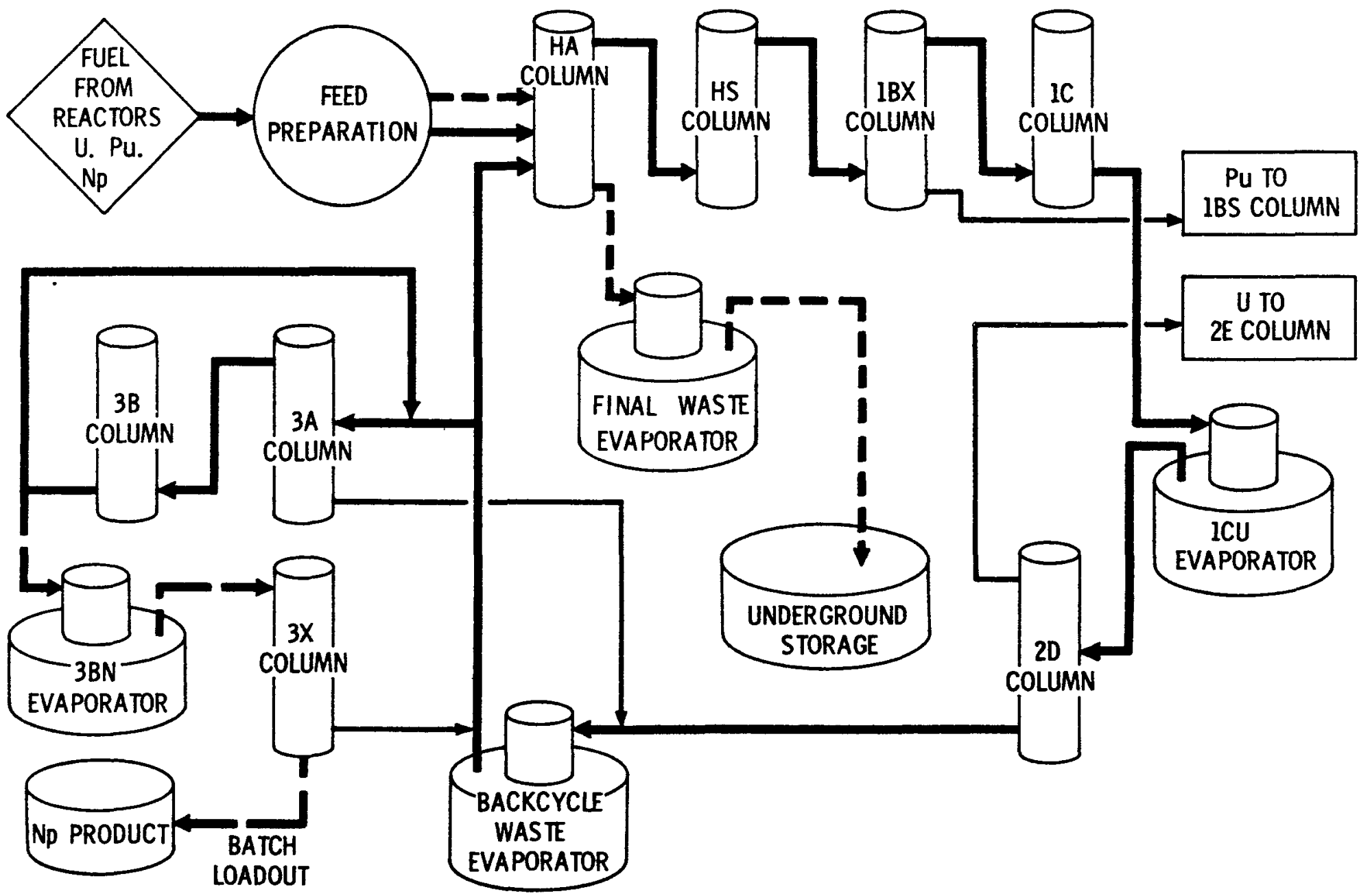


FIGURE 2

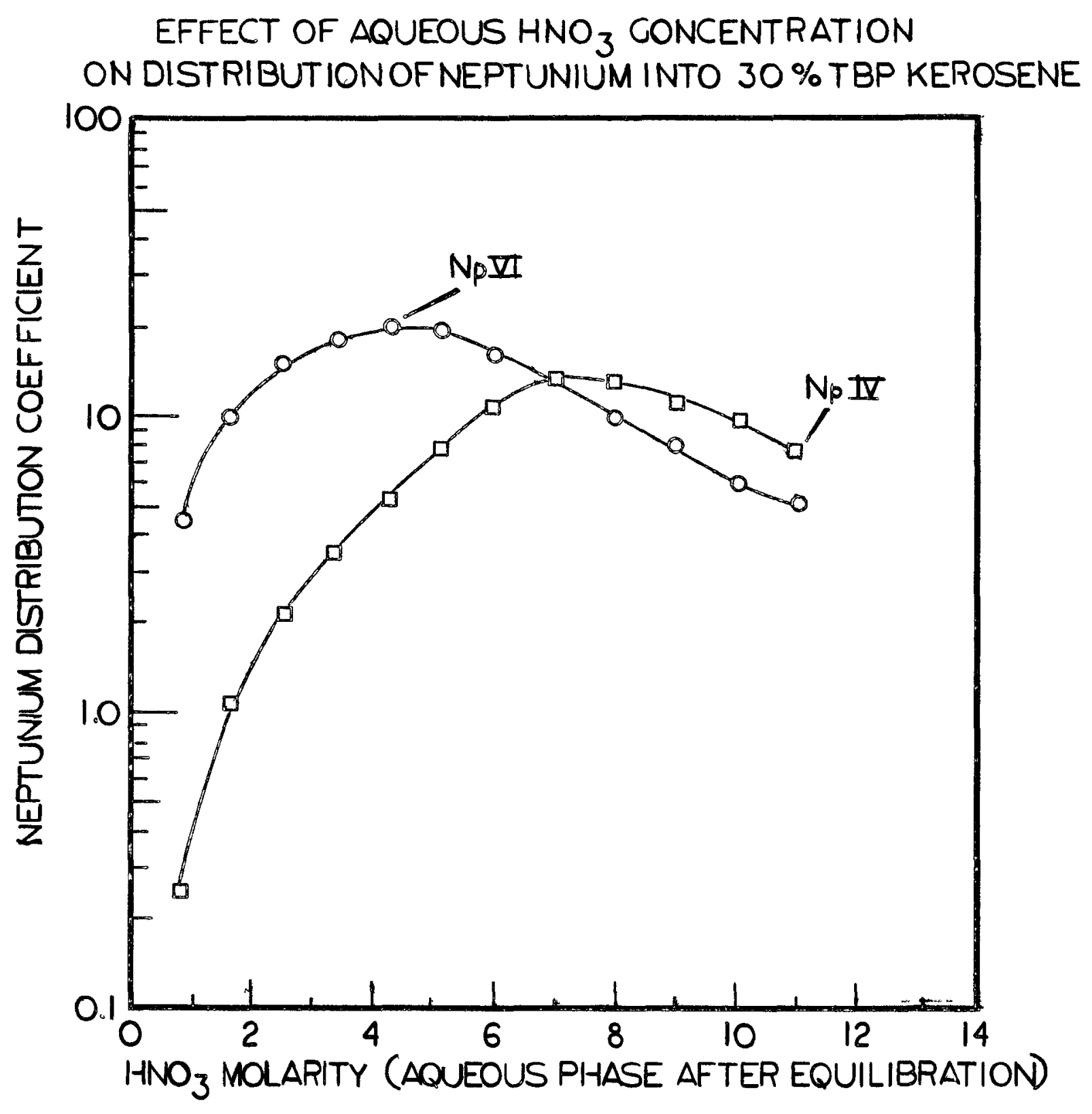


FTYURE 3

NEPTUNIUM RECOVERY AT PUREX

ACCUMUIATION PHASE FLOWSHEET

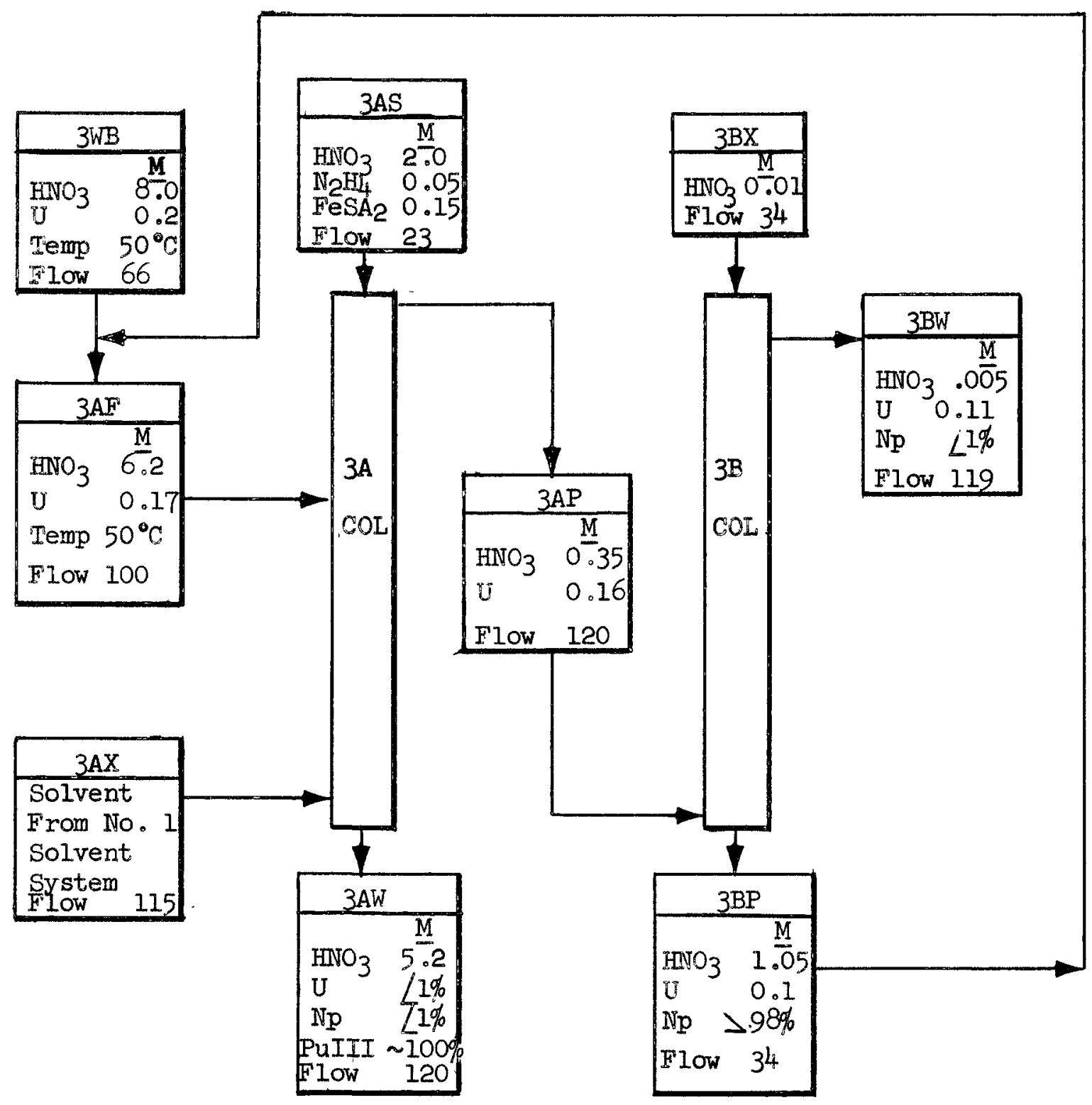


FIGURE 4

NEPTUNIUM RECOVERY AT PUREX

DECONTAMINATION PHASE FLOWSHEET

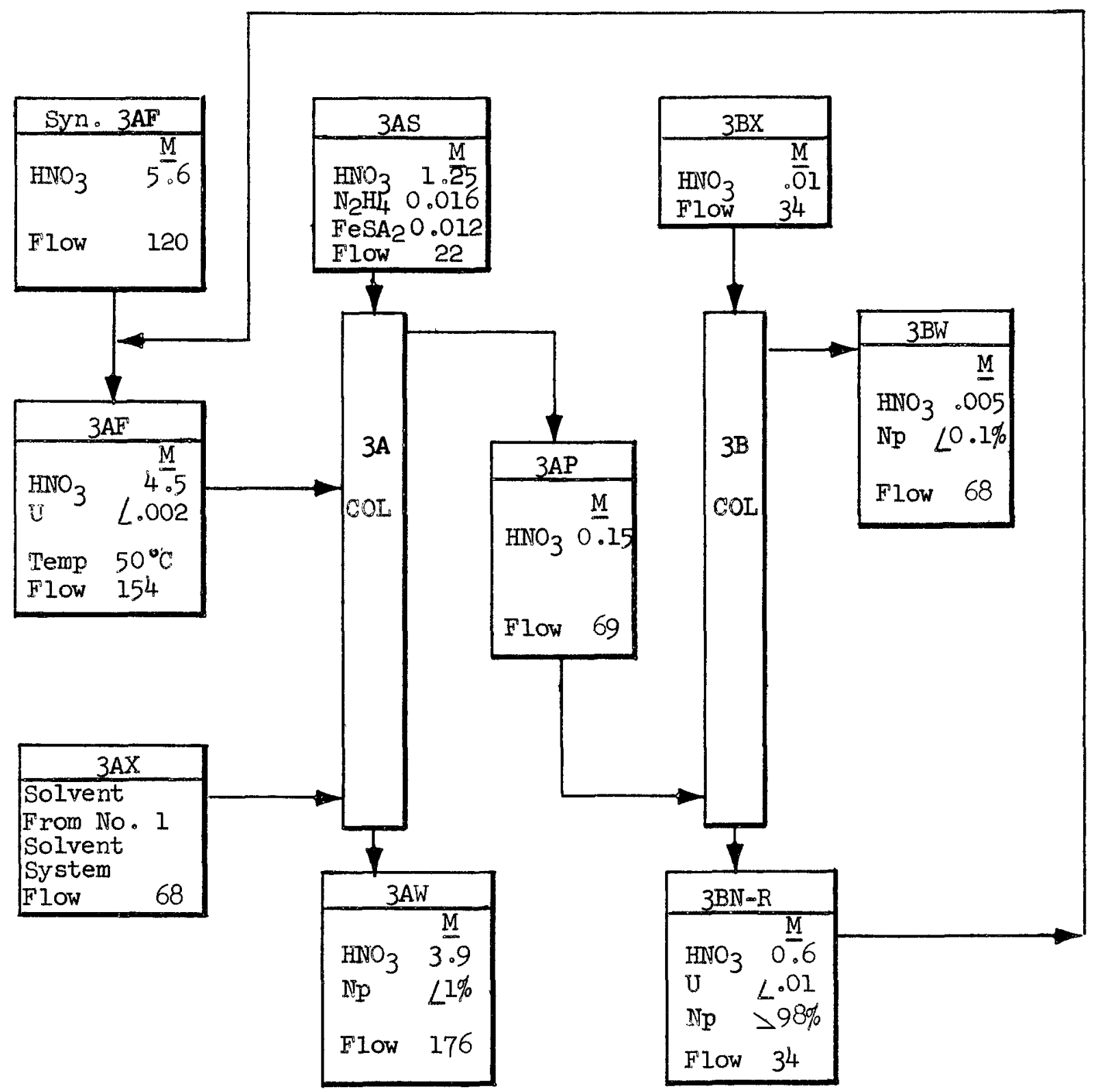




\section{FIGURE 5}

\section{NEPTUNIUM RECOVERY AT PUREX}

TYPICAL DECONTAMINATION PERFORMANCE

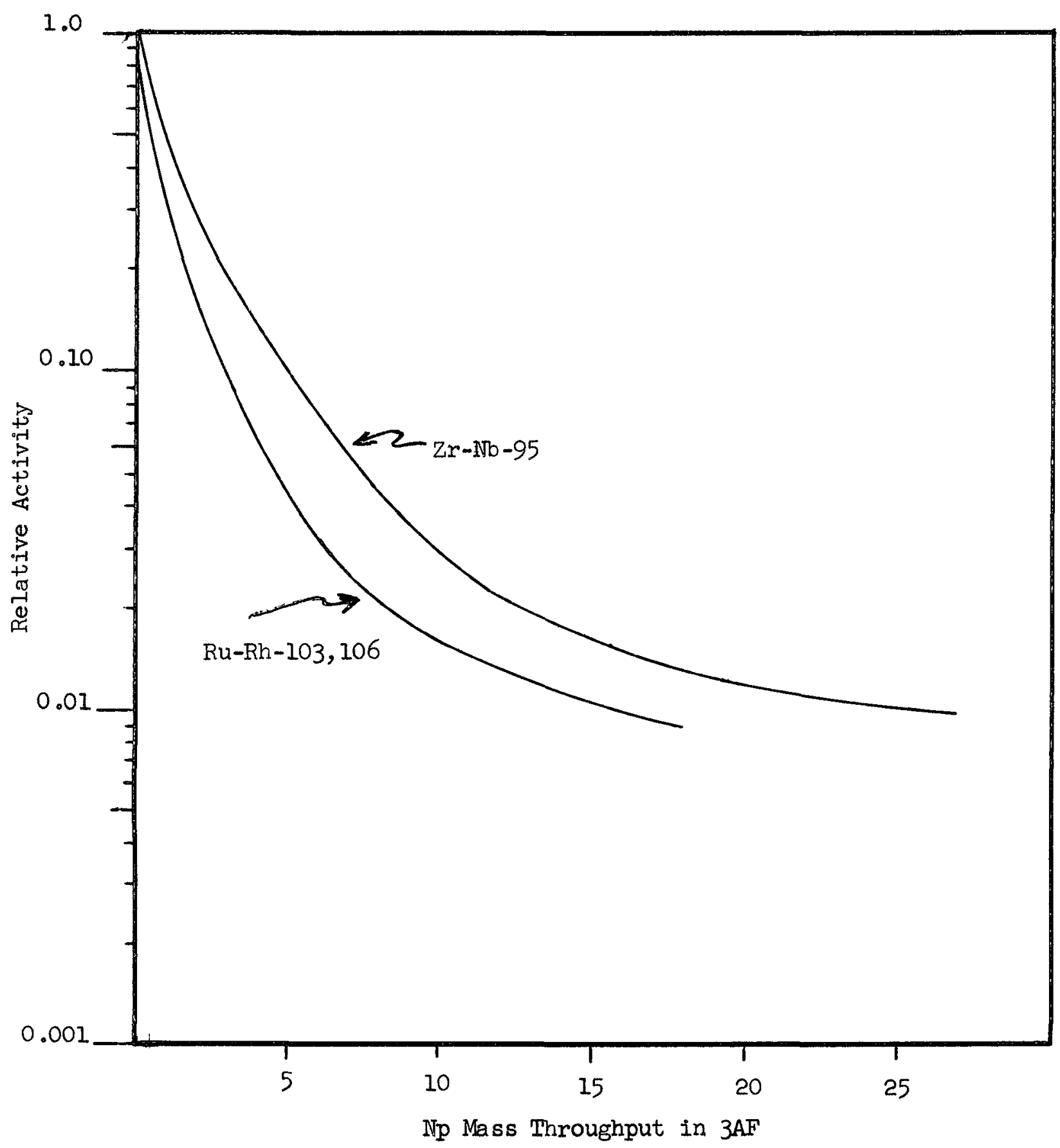


NEPTUNIUM RECOVERY FLOW DIAGRAM-BEFORE PROJECT CGC-913

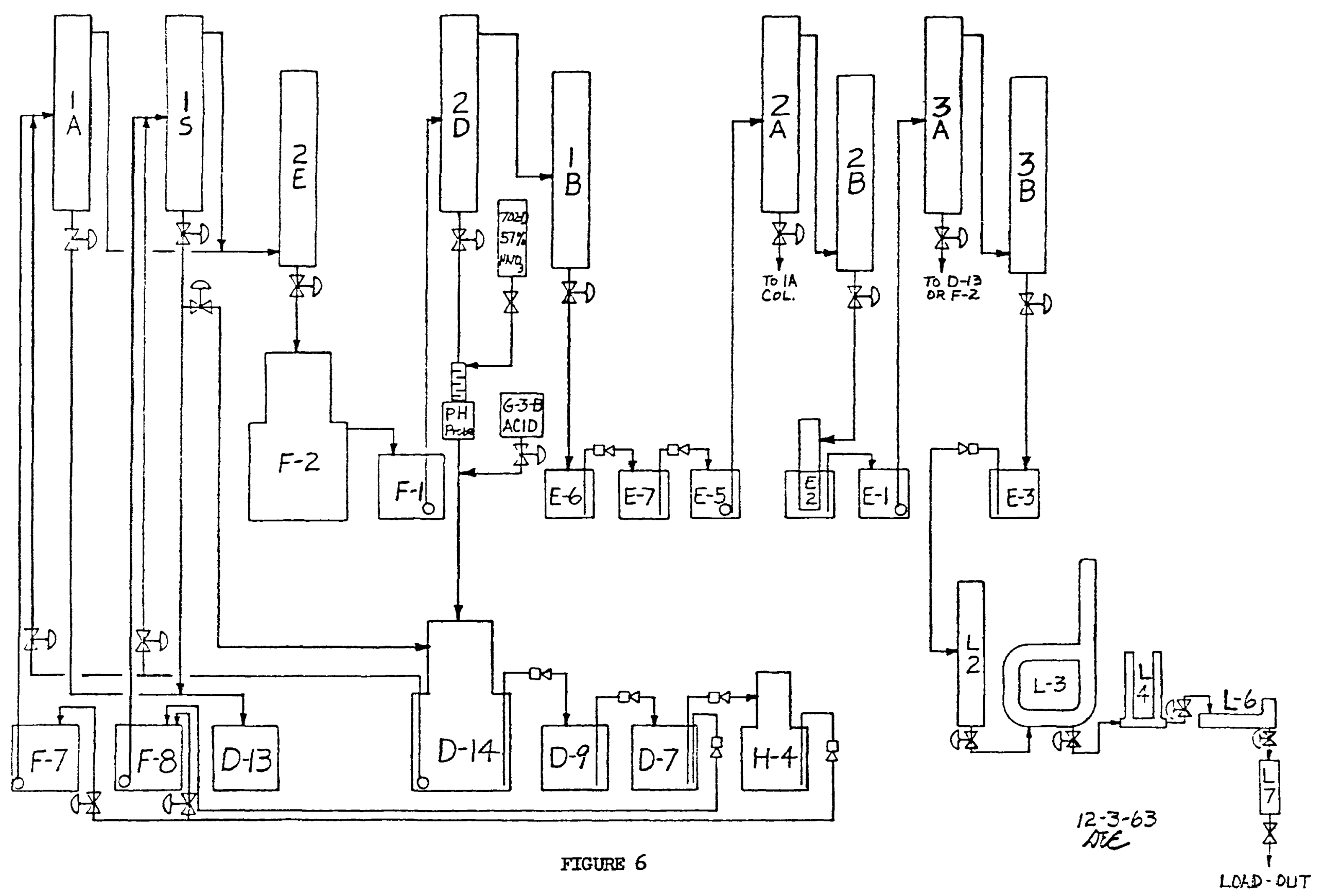


NEPTUNIUM RECOVERY FLOW DIAGRAM-AFTER PROJECT CGC-9/3

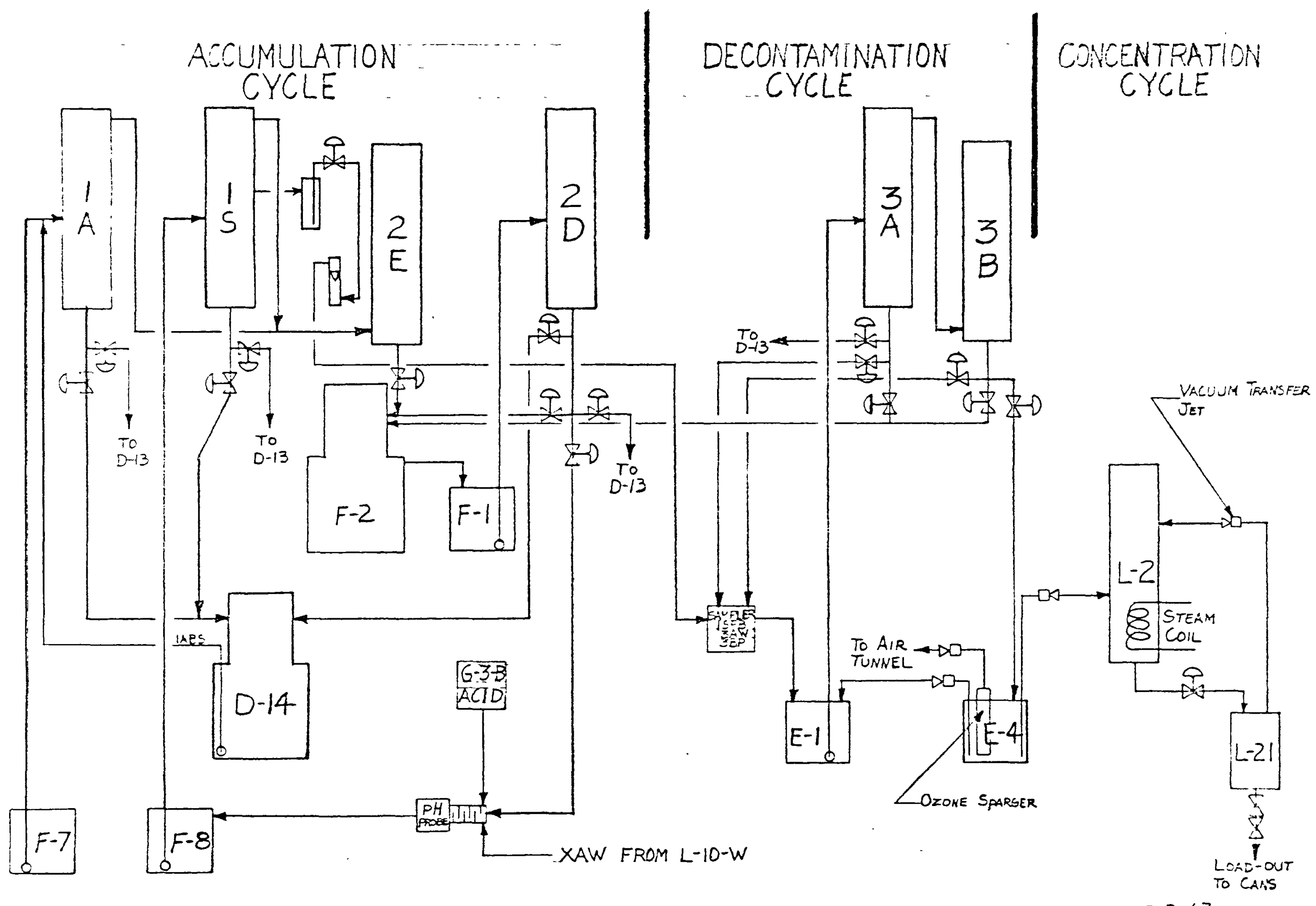


FIGURE 8

\section{EFFECT OF $p H$ ON Np $E_{q}^{\circ}$ UNDER REDOX EXTRACTION CONDITIONS}

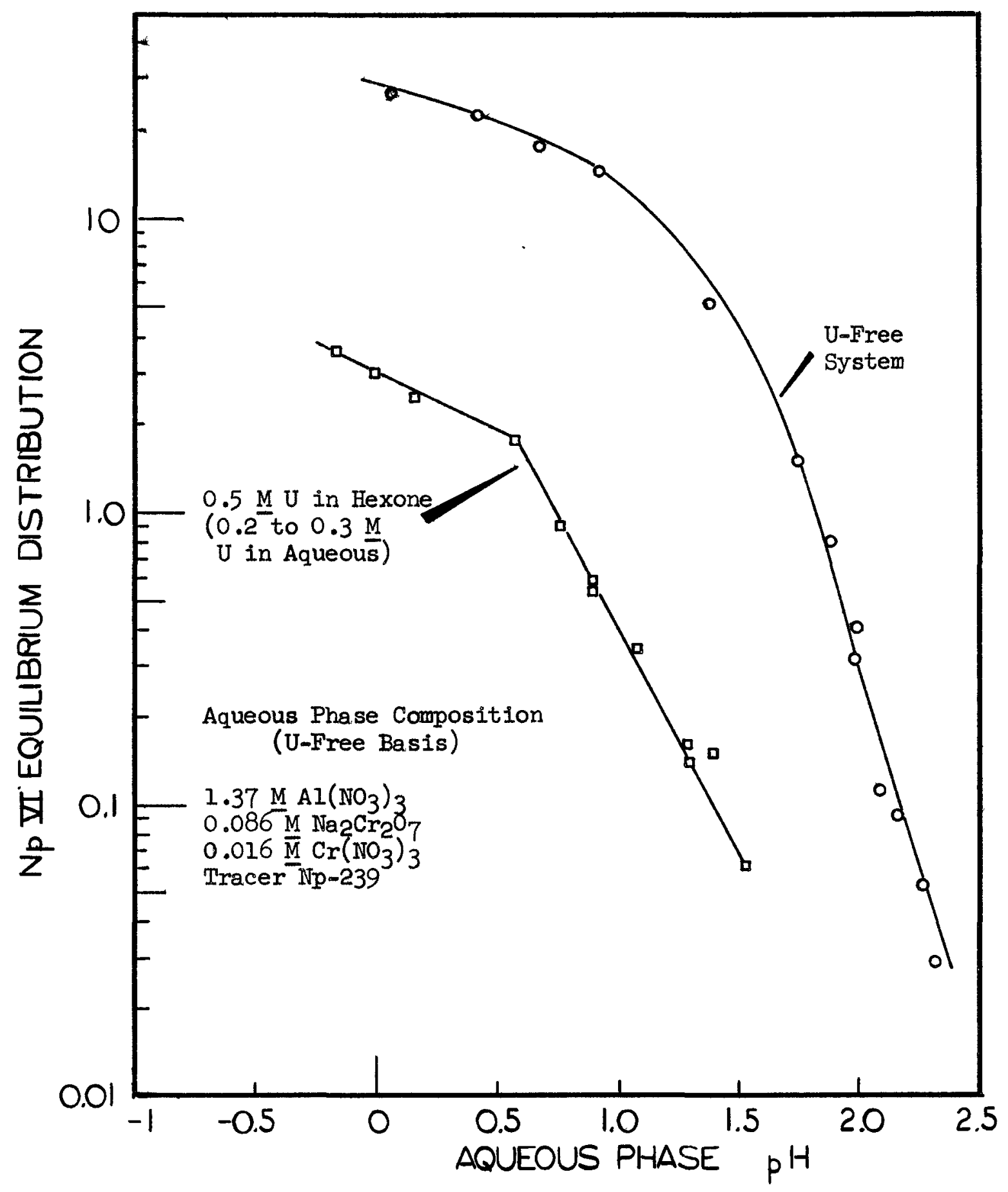




\section{BATCH ION EXCHANGE FIOWSCHEME}

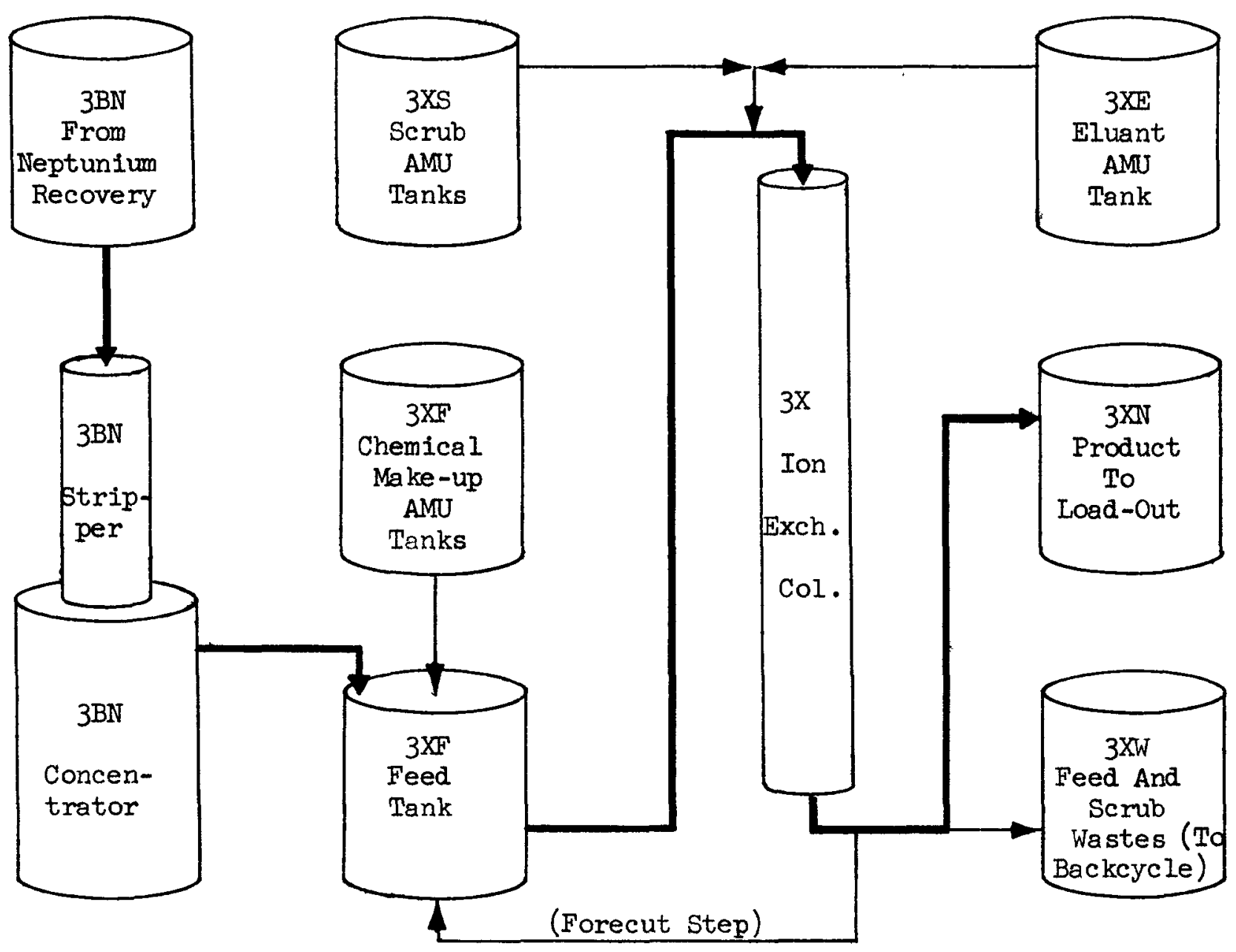

